\title{
Penerapan Metode Eksperimen Dan Model Pembelajaran Kooperatif Untuk Meningkatkan Hasil Pembelajaran IPA Dalam Mendeskripsikan Sifat-Sifat Cahaya Pada Siswa Kelas V SD
}

\author{
Sri Mulyati \\ SDN Negla 03 Kecamatan Losari \\ sriyati331983@gmail.com
}

\section{Article History}

received $3 / 12 / 2020$

accepted 31/12/2020

\begin{abstract}
This report is motivated by the findings in the field where the condition of the fifth grade students of SDN Negla 03 has the characteristics of relatifely low learning outcomes in science learning in the basic competency "Describe the Properties of Light". One alternative to help improve learning outcomes. The authors make improvements through the applications of eksperimental methods and cooperative learning models. This report describes the implementation and results of research onimproving learning on the use of eksperimental methods and cooperative learning models. The research used the CAR method which was carried out in 2 cycles. Each cycle consists of four stages including planning, implementation, observation and reflection. The subject of this research is the fifth grade student of SDN Negla 03. The instruments used in this research are qualitative and quantitative data. Qualitative data obtained trough student and teacher activity observation sheets, while quantitative data were obtained through formative tests. The results showed an increase in learning outcomes along with the increase in student activity, motivation and cooperation in learning. Thus, the application of cooperative learning models can improve student learning outcomes.
\end{abstract}

Keywords: learning outcomes, eksperiment methods and cooperative learning model

\begin{abstract}
Abstrak
Laporan ini dilatarbelakangi oleh adanya temuan di lapangan dimana kondisi siswa kelas V SDN Negla 03 memiliki karakteristik hasil belajar yang relative rendah dalam pembelajaran IPA pada Kompetensi Dasar "Mendeskripsikan Sifat-sifat Cahaya". Salah satu alternative untuk membantu meningkatkan hasil pembelajaran, penulis melakukan perbaikan melalui penerapan Metode Eksperimen dan model pembelajaran kooperatif. Laporan ini mendeskripsikan pelaksanaan dan hasil penelitian perbaikan pembelajaran terhadap penggunaan metode eksperimen dan model pembelajaran kooperatif. Penelitian menggunakan metode PTK yang dilaksanakan dalam 2 siklus. Tiap siklus terdiri dari empat tahap meliputi perencanaan, pelaksanaan, pengamatan dan refleksi. Subjek penelitian ini adalah siswa kelas V SDN Negla 03. Ada pun instrumenyang digunakan dalam penelitian ini adalah data kualitatif dan kuantitatif. Untuk data kualitatif diperoleh melalui lembar obsevasi aktivitas siswa dan guru, sedangkan data kuantitatif diperoleh melalui tes formatif. Hasil penelitian menunjukkan adanya peningkatan hasil belajar seiring meningkatnya keaktifan, motivasi dan kerjasama siswa dalam pembelajaran. Dengan demikian, penerapan model pembelajaran kooperatif dapat meningkatkan hasil belajar siswa.
\end{abstract}

Kata kunci: hasil belajar, metode eksperimen dan model pembelajaran kooperatif

Social, Humanities, and Education Studies (SHEs): Conference Series https://jurnal.uns.ac.id/shes

p-ISSN 2620-9284

e-ISSN 2620-9292

This work is licensed under a Creative Commons Attribution-ShareAlike 4.0 International License. 


\section{PENDAHULUAN}

Guru adalah faktor utama yang menentukan mutu pendidikan. Gurulah yang berada pada posisi terdepan dalam menciptakan kualitas sumber daya manusia. Guru berhadapan langsung dengan peserta didik di kelas melalui proses belajar-mengajar. Oleh karena itu, diperlukan sosok guru yang mempunyai kualifikasi, kompetensi, dan dedikasi yang tinggi dalam menjalankan tugas profesionalnya. Untuk menghadapi perkembangan zaman dan era globalisasi yang penuh persaingan dan ketidakpastian, dibutuhkan guru yang visioner dan mampu mengelola proses belajar mengajar yang visioner dan inovatif. Siswa atau anak didik adalah salah satu komponen manusiawi yang menempati posisi sentral dalam proses belajar-mengajar. Di dalam proses belajar mengajar, siswa sebagai pihak yang ingin meraih cita-cita, memiliki tujuan dan kemudian ingin mencapainya secara optimal. Siswa atau anak didik itu akan menjadi faktor penentu, sehingga menuntut dan dapat mempengaruhi segala sesuatu yang diperlukan untuk mencapai tujuan belajarnya. Jadi dalam proses belajar mengajar yang diperhatikan pertama kali adalah siswa atau anak didik, bagaimana keadaan dan kemampuannya, baru setelah itu menetukan komponen-komponen yang lain. Apa saja bahan yang diperlukan, bagaimana cara yang tepat untuk bertindak, alat dan fasilitas apa yang cocok dan mendukung, semua itu harus disesuaikan dengan keadaan/ karakteristik siswa. Itulah sebabnya siswa atau anak didik adalah merupakan subjek belajar.

Permasalahan yang berkenaan dengan siswa di kelas, jika tidak dicari solusi dan dibiarkan berlalu begitu saja, akan lebih kompleks dan berlarut-larut. Akibatnya, akan dirasakan pada ketidak kompetenan siswa di masyarakat yang berhubungan dengan materi pelajaran. Permasalahan siswa maupun guru selama proses belajar, menjadi prioritas, untuk secepatnya diteliti penyebab dan solusinya. Hal itu perlu dipahami oleh seorang guru karena keberhasilan belajar siswa ditentukan, sejauh mana guru memiliki inisiatif perbaikan terhadap prosedur dan hal yang berkaitan dengan proses yang telah dilakukan.

Sebagaimana pengalaman penulis selama ini bertugas menjadi guru kelas di SDN Negla 03, penulis menemukan beberapa gejala dalam mata pelajaran IPA Kompetensi Dasar "Mendeskripsikan Sifat-sifat Cahaya" di kelas V yaitu sebagai berikut :

1. Sebagian peserta didik tidak dapat menjawab pertanyaan dalam proses pembelajaran karena takut salah jika menjawab pertanyaan, dan kurang aktif.

2. Siswa belum berani bertanya bila ada kesulitan dalam pembelajaran.

3. Siswa belum mengetahui bagaimana cara kerja kelompok yang baik.

4. Murid sulit memahami materi yang disampaikan oleh guru di kelas.

5. Hasil belajar murid masih di bawah kriteria ketuntasan minimal (KKM) yang telah ditetapkan, yaitu dengan nilai rata- rata $27,27 \%$ dari jumlah 11 siswa sedangkan KKM yang telah ditetapkan di SDN Negla 03 adalah 65.

Berdasarkan masalah-masalah di atas, penulis berupaya meningkatkan keaktifan, motivasi, kerjasama dan prestasi belajar siswa dengan menerapkan metode eksperimen dan model pembelajaran kooperatif dalam pembelajaran IPA pada kompetensi dasar "Mendeskripsikan Sifat-sifat Cahaya".

\section{METODE}

Subjek dalam penelitian ini adalah seluruh siswa kelas V SDN Negla 03 tahun pelajaran 2019/2020 dengan jumlah siswa11 anak yang terdiri dari 5 siswa laki-laki dan 6 siswa perempuan. Objek dalam penelitian ini adalah penggunaan metode eksperimen dan model pembelajaran kooperatif untuk meningkatkan hasil pembelajaran IPA dalam mendeskripsikan sifat-sifat cahaya pada siswa kelas V SDN Negla 03. 
Penelitian tindakan kelas ini dilakukan di SDN Negla 03 Kecamatan Losari Kabupaten Brebes Provinsi Jawa Tengah. Adapun waktu penelitian ini direncanakan bulan Februari hingga April 2020. Mata pelajaran yang diteliti adalah mata pelajaran IPA. Setelah data terkumpul melalui observasi, data tersebut diolah dengan menggunakan rumus persentase, yaitu:

$$
\begin{aligned}
& p=\frac{\mathrm{F}}{\mathrm{N}} \times 100 \% \\
& \text { Keterangan: } \\
& \mathrm{f}=\text { Frekuensi yang sedang dicari persentasenya } \\
& \mathrm{N}=\text { Number of Cases (jumlah frekuensi/ banyaknya individu) } \\
& \mathrm{P}=\text { Angka persentase }
\end{aligned}
$$

\section{Kegiatan Siklus I}

\section{HASIL DAN PEMBAHASAN}

\section{a. Perencanaan Tindakan Sikus I}

Dalam menyusun tahap perencanaan atau persiapan tindakan ini, guru atau peneliti dibantu oleh teman sejawat. Adapun persiapan penelitian yang disusun adalah sebagai berikut:

1. Menyusun Rencana Perbaikan Pembelajaran.

2. Membuat lembar kerja kelompok, soal tes formatif serta mengadakan sumber dan media pembelajaran.

3. Menunjuk teman sejawat untuk menjadi observer.

b. Pelaksanaan Tindakan

Siklus pertama dilaksanakan pada tanggal 6 Maret 2020. Pelaksanaan pembelajaran dilakukan berdasarkan rencana pelaksanaan perbaikan (RPP) yang telah dipersiapkan. Pada siklus I peneliti melakukan perbaikan pembelajaran melalui aktivitasaktivitas sebagai berikut : 1).Guru membagi siswa menjadi 3 kelompok yang heterogen. Secara klasikal guru mencobakan peristiwa pembiasan cahaya. Tiga orang perwakilan dari 3 kelompok mengamati hasil percobaan. Saat eksperimen guru dan siswa melakukan Tanya jawab. 2). Secara kelompok siswa aktif mencobakan kembali peristiwa pembiasan dan mendiskusikan hasil eksperimen sesuai pedoman yang ada pada lembar kerja kelompok. Dalam kegiatan ini guru membimbing dan memantau pekerjaan siswa. Bagi siswa yang mempunyai kemampuan lebih dijadikan tutor sebaya bagi anggota kelompoknya. Dalam pembahasan secara klasikal, setiap juru bicara kelompok menyampaikan hasil diskusinya dan kelompok lain menanggapinya. Apabila semua jawaban dari tiap kelompok belum ada yang benar guru bersama siswa menyempurnakan jawaban siswa. 3). Untuk menjelaskan materi tentang penguraian cahaya dan menunjukkan bukti bahwa cahaya putih itu terdiri dari berbagai warna, guru mengajak siswa ke luar ruangan yang ada panas matahari. Secara klasikal guru dan siswa melakukan percobaan membuat pelangi menggunakan baskom, air jernih, cermin datar dan kertas manila putih. Kemudian guru dan siswa melakukan Tanya jawab mengenai peristiwa pelangi. 4). Guru mengarahkan siswa membuat kesimpulan materi pelajaran

Setelah kegiatan awal dan kegiatan inti dilaksanakan dilanjutkan dengan kegiatan akhir. Untuk melihat hasil perbaikan pembelajaran pada kegiatan penutup peneliti mengadakan tes formatif. Dalam pelaksanaan perbaikan pembelajaran pada siklus I ini peneliti diamati oleh teman sejawat.

\section{c. Observasi dan Refleksi}

Berdasarkan hasil lembar observasi tentang keaktifan, motivasi dan kerjasama siswa pada siklus I dapat dideskripsikan bahwa untuk keaktifan dan motivasi ada 27,27\% 
berpredikat sangat baik, 45,45\% berpredikat baik, 9,09\% berpredikat cukup, dan 18,18\% berpredikat kurang. Untuk aspek kerjasama ada 36,36\% berpredikat sangat baik, $27,27 \%$ berpredikat baik, $18,18 \%$ berpredikat cukup dan $18,18 \%$ berpredikat kurang. Nilai rata-rata assessment aktifitas siswa pada siklus I adalah 3,7 dengan predikat cukup.

Berdasarkan hasil tes formatif yang dilakukan siswa pada siklus I terlihat bahwa hasil belajar siswa mengalami peningkatan. Pada data sebelumnya persentase ketuntasan kelas hanya mencapai $27,27 \%$ dengan nilai rata-rata kelas 56,36 . Sedangkan setelah diterapkannya tindakan pada siklus I ini persentase ketuntasan kelasnya mengalami peningkatan yaitu mencapai $72,73 \%$.

Refleksi pada siklus I diperoleh berdasarkan hasil analisis data pada pembelajaran perbaikan siklus I. Berdasarkan hasil observasi pada siklus I ini masih terdapat aspek kegiatan yang dianggap belum baik yaitu pelaksanaan kerja kelompok, masih ada satu kelompok yang memperoleh nilai di bawah 75 dan pelaksanaannya melewati batas waktu yang ditentukan. Hal tersebut disebabkan karena adanya sifat egois salah satu anggota kelompok yang tidak menghargai teman-temannya sehingga diskusi didominasi oleh salah satu anggota kelompok dari kelompok tersebut. Guru kurang memberikan arahan pada tiap kelompok tentang aspek-aspek kerjasama yang baik.

\section{Kegiatan Siklus II}

\section{a. Perencanaan Tindakan Siklus II}

Persiapan yang dilakukan peneliti untuk pelaksanaan perbaikan pembelajaran pada siklus II sebagai berikut:

1) Menyusun rencana perbaikan pembelajaran siklus II.

2) Menunjuk teman sejawat untuk menjadi observer.

3) Lebih meningkatkan kerjasama siswa dan meningkatkan kemampuannya dalam membimbing siswa dalam pembelajaran kooperatif.

\section{b. Pelasanaan Tindakan}

Siklus kedua dilaksanakan 16 Maret 2020. Pelaksanaan pembelajaran dilakukan berdasarkan rencana pelaksanaan perbaikan (RPP) yang telah dipersiapkan. Pada siklus II peneliti melakukan perbaikan pembelajaran melalui aktivitas-aktivitas sebagai berikut : 1). Guru mengajak siswa keluar ruangan yang ada panas matahari. Secara klasikal guru dan siswa aktif melakukan percobaan membuat pelangi dengan media baskom, cermin datar, air dan kertas manila putihuntuk membuktikan bahwa cahaya putih terdiri dari berbagai warna dan menjelaskan satu contoh peristiwa dalam melakukan percobaan, mengamati proses dan hasil percobaan. 2). Secara kelompok siswa aktif mencobakan eksperimen lain untuk membandingkannya dengan eksperimen pertama dan mendiskusikan hasil eksperimen sesuai pedoman yang ada pada lembar kerja kelompok. Dalam kegiatan ini guru membimbing dan memantau pekerjaan siswa. Siswa yang mempunyai kemampuan lebih dijadikan tutor sebaya bagi anggota kelompoknya. Dalam pembahasan secara klasikal, setiap juru bicara kelompok menyampaikan hasil diskusinya dan kelompok lain menanggapinya dengan sanggahan dan memberikan jawaban yang tepat. Apabila semua jawaban dari tiap kelompok belum ada yang benar, guru bersama siswa menyempurnakan jawaban siswa. 3). Secara klasikal guru dan siswa mengadakan Tanya jawab mengenai materi yang baru saja disampaikan. 4). Siswa dengan bimbingan guru menyimpulkan materi pelajaran. Untuk melihat hasil perbaikan pembelajaran, pada kegiatan penutup peneliti mengadakan tes formatif.

\section{c. Observasi dan Refleksi}

Berdasarkan hasil lembar observasi tentang keaktifan, motivasi dan kerjasama siswa pada siklus II dapat dideskripsikan bahwa untuk keaktifan ada 36,36\% berpredikat sangat baik, 45,45\% berpredikat baik, dan 18,18\% berpredikat cukup. Untuk aspek motivasi ada $36,36 \%$ berpredikat sangat baik, 54,54\% berpredikat baik, dan 9,09\% 
berpredikat cukup. Untuk aspek kerjasama ada 27,27\% berpredikat sangat baik, 54,54\% berpredikat baik dan18,18\% berpredikat cukup. Nilai rata-rata assessment aktifitas siswa pada siklus II adalah 4,2 dengan predikat baik.

Berdasarkan hasil tes formatif yang dilakukan siswa pada siklus II lebih meningkat dibandingkan pra siklus dan siklus I dengan persentase ketuntasan kelas 90,9\%.

Refleksi pada siklus II diperoleh berdasarkan hasil analisis data pada pembelajaran perbaikan siklus II. Berdasarkan hasil observasi pada siklus II ini :

1. Guru menyediakan alat peraga yang cukup sehingga siswa dapat terlibat aktif dalam pelaksanaan eksperimen dan pembelajaran kooperatif.

2. Guru memberikan penjelasan dengan jelas, rinci dan sistematis sehingga siswa mudah memahami materi.

3. Siswa terlibat aktif dalam pelaksanaan eksperimen. Guru membimbing siswa pada pelaksanaan eksperimen.

4. Siswa sangat antusias dalam menjawab pertanyaan guru.

5. Waktu pelaksanaan pembelajaran kooperatif berjalan efisien dan tepat waktu. Guru membimbing siswa saat pembelajaran. Siswa menyajikan hasil pembelajaran dengan baik. Pelaksanaan pembelajaran kooperatif yang sebelumnya dianggap belum baik,pada siklus II ini dianggap sudah baik.

6. Guru membimbing siswa dalam menyimpulkan materi pelajaran.

Dalam penelitian ini, mencari apakah metode eksperimen dan model pembelajaran kooperatif dapat meningkatkan hasil pembelajaran IPA dalam mendeskripsikan sifatsifat cahaya siswa kelas V SDN Negla 03.

Hasil belajar siswa pada tahap pra siklus tergolong kurang hanya $27,27 \%$ dari jumlah siswa yang mengalami belajar tuntas sedangkan $72,73 \%$ lainnya mendapatkan nilai di bawah 70 atau belum mengalami belajar tuntas. Setelah dilakukan tindakan perbaikan pada siklus I persentase ketuntasan kelasnya mengalami peningkatan yaitu mencapai $72,73 \%$. Pada perbaikan pembelajaran siklus II hasil persentase ketuntasan kelasnya lebih meningkat lagi yaitu 90,9\%.

Dari rangkaian kegiatan perbaikan pembelajaran pada siklus I dan siklus II dapat ditemukan kelebihan dan kelemahan metode eksperimen dan model pembelajaran kooperatif. Keunggulan metode eksperimen antara lain : dapat membangkitkan rasa ingin tahu siswa, dapat membangkitkan rasa ingin menguji sesuatu, menimbulkan rasa kurang puas ingin lebih baik, isi pembelajaran dapat bersifat aktual, siswa mampu membuktikan sesuatu, dapat mengembangkan sikap kritis dan ilmiah, dan belajar membuktikan sesuatu. Sedangkan kelemahan pada metode eksperimen yaitu memerlukan alat pembelajaran dan biaya, memerlukan waktu yang relative banyak, apabila siswa kurang motivasi maka eksperimen tidak akan sukses, dan siswa belum terbiasa dengan eksperimen. Sama halnya dengan metode eksperimen, model pembelajaran kooperatif juga memiliki kelebihan dan kelemahan. Kelebihan pembelajaran kooperatif adalah : saling ketergantungan yang positif, adanya pengakuan dalam merespon perbedaan individu, siswa dilibatkan dalam perencanaan dan pengelolaan kelas, suasana kelas yang rileks dan menyenangkan, terjalinnya hubungan yang hangat dan bersahabat antara siswa dengan guru, dan memiliki banyak kesempatan untuk mengekspresikan pengalaman emosi yang menyenangkan. Kelemahan model pembelajaran kooperatif antara lain : sering melebihi waktu yang telah dialokasikan, diskusi terkadang didominasi seseorang sehingga mengakibatkan siswa yang lain menjadi pasif.

Berdasarkan pelaksanaan perbaikanpembelajaran dapat disimpulkan bahwa kelemahan-kelemahan metode eksperimen dan model pembelajaran kooperatif pada siklus I dapat diperbaiki pada siklus II sehingga penggunaan metode eksperimen dan model pembelajaran kooperatif dapat meningkatkan hasil pembelajaran IPA dalam mendeskripsikan sifat-sifat cahaya pada siswa kelas V SDN Negla 03 tahun pelajaran 2019/2020. 


\section{SIMPULAN}

Berdasarkan temuan dan pembahasan hasil penelitian dapat disimpulkan bahwa penggunaan metode eksperimen dan model pembelajaran kooperatif dapat meningkatkan hasil pembelajaran IPA dalam mendeskripsikan sifat-sifat cahaya pada siswa kelas V SDN Negla 03 Kecamatan Losari Kabupaten Brebes Provinsi Jawa Tengah tahun pelajaran 2019/2020.

Bertolak dari keberhasilan penelitian yang dilakukan, penulis menyampaikan saran kepada rekan-rekan guru agar siswa mencapai prestasi belajar yang baik dalam pembelajaran IPA, guru hendaknya:

1) Memanfaatkan media pembelajaran dengan baik.

2) Melaksanakan eksperimen untuk membangkitkan rasa ingin tahu siswa.

3) Menyampaikan materi secara efektif dan jelas.

4) Melakukan Tanya jawab untuk mengaktifkan siswa.

5) Melaksanakan model pembelajaran kooperatif untuk memotivasi dan mengaktifkan siswa dalam belajar.

\section{DAFTAR PUSTAKA}

BNSP. 2007. Standar Isi untuk Satuan Pendidikan Dasar dan Menengah. Jakarta : Departemen Pendidikan Nasional.

Dimyati dan Mudjiono. 2002. Belajar dan Pembelajaran, Jakarta: Rineka Cipta

Sardiman. 2004. Interaksi dan Motivasi Belajar Mengajar. Jakarta: Rajawali Pers

Slameto. 2003. Belajar Dan Faktor-Faktor Yang Mempengaruhinya. Jakarta: Rineka Cipta

Sudjono, Anas. 2004. Pengantar Statistik Pendidikan. Jakarta: Raja Grafindo Persada Supriono, Agus. 2009 Cooperative Learning. Yogyakarta: Pustaka Pelajar Tu'u, Tulus. 2004. Peran Disiplin Pada Perilaku dan Prestasi Siswa. Jakarta: Grasindo UU Sisdiknas No.20 Tahun 2008

Permendiknas No.22 Tahun 2006. 